\title{
PATH ANALYSIS ON THE BIOPSYCHOSOCIAL FACTORS INFLUENCING THE QUALITY OF LIFE OF ELDERLY IN SURAKARTA CENTRAL JAVA
}

\author{
Dwi Tour Kumalasari'), Bhisma Murti'1), Vitri Widyaningsih²) \\ ${ }^{1)}$ Masters Program in Public Health, Universitas Sebelas Maret \\ 2)Faculty of Medicine, Universitas Sebelas Maret
}

\begin{abstract}
Background: Health-related quality of life (HRQoL) is a commonly used measure of health outcome. It reflects several dimensions of health, including physical, psychological, social, cognitive function, as well as general well-being, including in elderly population. The association between social capital and HRQoL in elderly has been rarely studied in Indonesia. The purpose of this study was to investigate the biopsychosocial factors influencing the quality of life of elderly using path analysis.

Subjects and Method: A cross sectional study was conducted in Surakarta, Central Java, in December 2019. A sample of 200 elderly was selected by simple random sampling. The dependent variable was quality of life. The independent variables were education, income, marital status, body mass index (BMI), physical activity, locus of control, family support, peer support, social capital. The data were collected by questionnaire and analyzed by path analysis run on Stata 13.

Results: Quality of life in elderly was directly increased by high physical activity $(b=2.01$; $95 \% \mathrm{CI}=0.55$ to $3.45 ; \mathrm{p}=0.007)$, education $\geq$ Elementary school $(\mathrm{b}=2.38 ; 95 \% \mathrm{CI}=0.79$ to 3.97; $\mathrm{p}=0.003)$, BMI 18.5 to $25(\mathrm{~b}=3.45 ; 95 \% \mathrm{CI}=1.60$ to $5.30 ; \mathrm{p}<0.001)$, income $\geq \mathrm{Rp}$ $1,800,000(b=2.96 ; 95 \% \mathrm{CI}=1.33$ to $4.59 ; \mathrm{p}<0.001)$, strong social capital $(\mathrm{b}=2.01 ; 95 \% \mathrm{CI}=$ 0.56 to $3.44 ; \mathrm{p}=0.006)$, married $(\mathrm{b}=2.15 ; 95 \% \mathrm{CI}=0.63$ to $3.67 ; \mathrm{p}=0.005)$, and internal locus of control $(b=2.29 ; 95 \% \mathrm{CI}=0.69$ to $3.90 ; \mathrm{p}=0.005)$. Quality of life in elderly was directly increased by physical activity, education, peer support, social capital, and marital status.

Conclusion: Quality of life in elderly is directly increased by high physical activity, education $\geq$ Elementary school, BMI 18.5 to 25 , income $\geq R p 1,800,000$, strong social capital, married, and internal locus of control. Quality of life in elderly is directly increased by physical activity, education, peer support, social capital, and marital status.
\end{abstract}

Keywords: quality of life, biopsychosocial, path analysis, elderly

Correspondence:

Dwi Tour Kumalasari. Masters Program in Public Health, Universitas Sebelas Maret. Jl. Ir. Sutami 36A, Surakarta 57126, Central Java, Indonesia. Email: kumalasari.azzahra@gmail.com. Mobile: +6281216417536.

The $7^{\text {th }}$ International Conference on Public Health Solo, Indonesia, November 18-19, 2020 | 86 https://doi.org/10.26911/the7thicph.01.41 